\title{
Synergistic Effects in the Inhibition of Copper Corrosion
}

\author{
S. Gonzalez, M.M. Laz, R.M. Souto, ${ }^{*}$ R.C. Salvarezza, and A.J. Arvia**
}

\section{ABSTRACT}

Benzotriazole (BTA), thiourea (TU), and potassium ethylxanthate (KEX), behave as copper ( $\mathrm{Cu}$ ) corrosion inhibitors under certain conditions. These chemicals have been investigated to establish whether they provide synergistic effects. The Cu corrosion inhibition was followed through changes in electrochemical characteristics. $\mathrm{Cu}$ specimens were tested at $25^{\circ} \mathrm{C}$ in two aggressive media, 0.1 $\mathrm{M} \mathrm{NaCl}$ and $1 \mathrm{M} \mathrm{NaClO}_{4}$, using the linear potential sweep technique at $0.001 \mathrm{~V} \mathrm{~s}^{-1}$ and by scanning electron microscopy of Cu specimens subjected to potentiodynamic and potentiostatic routines. A comparative behavior of the different substances for $\mathrm{Cu}$ was presented in the $6.6 \leq \mathrm{pH} \leq$ 11 range. For KEX-BTA mixtures, synergistic inhibition effects were found in $0.1 \mathrm{M} \mathrm{NaCl}(7 \leq \mathrm{pH} \leq 11)$. The apparent synergistic inhibition was explained tentatively by an increase in the compactness of the polymer-like passivating layer of $K E X-C u$, which formed in the presence of BTA and Cl ions.

KEY WORDS: benzotriazole, copper pitting, potassium ethylxanthate, synergistic inhibiting effects, thiourea

INTRODUCTION

The performance of some known inhibitors of copper (Cu) corrosion at $\mathrm{pH} \geq 4.0$, such as benzotriazole

Submitted for publication August 1992; in revised form, November 1992

* Departamento de Quimica Fisica, Universidad de La Laguna, 38204 La Laguna, Tenerife, Spain.

** INIFTA, Universidad Nacional de La Plata, La Plata, Argentina.
(BTA), can be improved by the addition of certain substances such as benzylamine and ethanolamine. ${ }^{1-3}$

Benzylamine has an inhibiting effect on $\mathrm{Cu}$ oxide formation but produces a synergistic effect on the corrosion inhibition of $\mathrm{Cu}$. A comparable enhanced protective effect on Cu corrosion was observed when BTA was present with potassium ethylxanthate (KEX) in an aggressive solution containing $\mathrm{Cl}^{-}$ions at $\mathrm{pH} \cong 7.4$

The residual passivating current of $\mathrm{Cu}$ in $0.1 \mathrm{M}$ $\mathrm{NaCl}+1 \mathrm{mM} \mathrm{BTA}$ was small. The passivating range extended from -0.50 to $-0.15 \mathrm{~V}$ vs saturated $\mathrm{NaCl}$ calomel electrode (SCE). The residual current of $\mathrm{Cu}$ in $0.1 \mathrm{M} \mathrm{NaCl}+3 \mathrm{mM} \mathrm{KEX}$ was greater. However, the passivity range covered -0.50 to $0.30 \mathrm{~V}_{\mathrm{SCE}}$. Therefore, the performance of BTA as a corrosion inhibitor for $\mathrm{Cu}$ corrosion in $\mathrm{Cl}^{-}$ion containing solution was expected to improve with the addition of KEX.

The behavior of several substances proposed as $\mathrm{Cu}$ corrosion inhibitors were investigated in different aggressive media. ${ }^{4,5}$ Comparison of the electrochemical characteristics of $\mathrm{Cu}$ in solutions containing the different substances allowed synergistic inhibition effects on Cu corrosion to be observed when two of those substances were present in the aggressive media, as for BTA-KEX in $0.1 \mathrm{M} \mathrm{NaCl}$. The effects were explained tentatively by the irreversible formation of coadsorbates leading to a protective heterogeneous polymeric-type layer, probably involving $\mathrm{Cu}$ complexes and adsorbed $\mathrm{Cl}^{-}$ions. 
EXPERIMENTAL

An electrochemical cell with three cylindrical electrodes (specimens) were made from electrolytic $\mathrm{Cu}$ rods of $99.99 \%$ purity. The specimens were treated thermally at $500^{\circ} \mathrm{C}$ under $3 \mathrm{~mm}$ argon (Ar) gas pressure for $2 \mathrm{~h}$ and then electropolished in $85 \%$ $\mathrm{H}_{3} \mathrm{PO}_{4}{ }^{6}$ Each specimen was mounted in a vertical conducting shaft. Contact between the base of the cylindrical electrode and the solution was made through the hanging meniscus technique. ${ }^{7}$ This arrangement avoided border effects that could lead to crevices. The geometric area of the working electrode was between 0.04 and $0.07 \mathrm{~cm}^{2}$. The potential of the working electrode was determined against a saturated $\mathrm{NaCl}$ calomel electrode (SCE). A large-area cylindrical platinum grid around the specimen was used as the counterelectrode.

Measurements were made at $25.0 \pm 0.1^{\circ} \mathrm{C}$. Solutions were prepared from twice-distilled water and analytical reagent chemicals and purged with $\mathrm{Ar}$ before each run. Solutions of $0.1 \mathrm{M} \mathrm{NaCl}$ and $1 \mathrm{M} \mathrm{NaClO}_{4}$ $\left(\mathrm{Cl}^{-}\right)$ion concentration lower than $10^{-5} \mathrm{M}$ ) were used. Thiourea (TU), BTA, and KEX were added as inhibitors and as TU-BTA and KEX-BTA mixtures. The total inhibitor concentration $\left(\mathrm{c}_{\mathrm{i}}\right)$ varied in the $1 \mathrm{mM} \leq \mathrm{c}_{i} \leq$ $3 \mathrm{mM}$ range. The initial solution $\mathrm{pH}$ was in the $5.6 \leq \mathrm{pH}$ $\leq 7.8$ range. It was adjusted to a preset $\mathrm{pH}$ value in the $6 \leq \mathrm{pH} \leq 11$ range by adding diluted $\mathrm{NaOH}$ solution.

Each run was begun with a new Cu specimen and a fresh stagnant solution under Ar atmosphere. The specimen was held at $E_{c}=-0.80 \mathrm{~V}$ for 3 min before each run and then subjected to a positive potential scan at $0.001 \mathrm{~V} \mathrm{~s}^{-1}$.

The potential scan was extended to the anodic switching potential, at which a $\mathrm{Cu}$ attack could be observed. For some specimens, pitting corrosion was confirmed through conventional potentiostatic experiments and scanning electron microscopy (SEM) observations.

Micrographs of the Cu electrode surfaces were imaged at different stages of the polarization curve with a Hitachi S $-450^{\dagger}$ scanning electron miscroscope for beam energies in the 20 to $25 \mathrm{keV}$ range.

\section{RESULTS}

\section{Polarization Curves}

The apparent current density (j) vs potential (E) profiles run in the positive and negative potential directions at $0.001 \mathrm{~V} \mathrm{~s}^{-1}$ in the different aggressive media (6. $2 \leq \mathrm{pH} \leq 7.6$ range), are shown in Figures 1 and 2 . The polarization curves generally exhibited a passive-like range (Region 1 ), preceding a rapid

\footnotetext{
† Trade name.
}

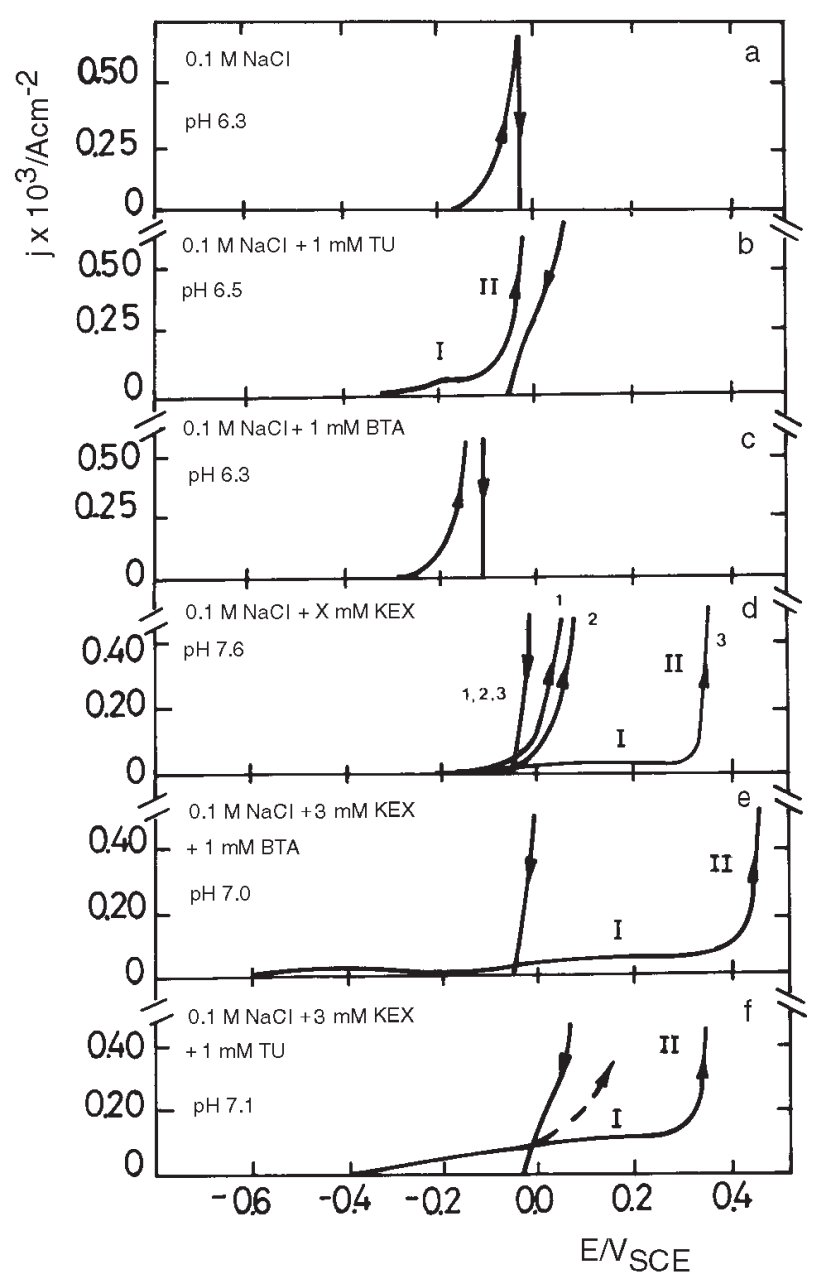

FIGURE 1. Polarization curves of electropolished, annealed Cu specimens run at $v=0.001 \mathrm{~V} \mathrm{~s}^{-1}$ from $E_{s, c}=-0.80 \mathrm{~V}$ in 0.1 $M \mathrm{NaCl}$ containing different inhibitors (6. $3 \leq \mathrm{pH} \leq 7.1$ range) at $25^{\circ} \mathrm{C}$. In (1d) $x=1 \mathrm{mM}(1) ; x=2 \mathrm{mM}(2)$ and $x=3 \mathrm{mM}$ (3). Arrows indicate the potential scan direction. The reverse scan is drawn to $E_{r^{\prime}}$ (f) Two independent positive potential scans show the variation of the experimental data.

increase in the anodic current (Region 2), and a counterclockwise hysteresis loop, which was typical of a localized anodic attack of the metal. This behavior was observed for $\mathrm{Cu}$ in all solutions except in $0.1 \mathrm{M}$ $\mathrm{NaCl}(\mathrm{pH} 6.3), 1 \mathrm{M} \mathrm{NaClO}_{4}(\mathrm{pH} \mathrm{6.6)}$, and $0.1 \mathrm{M} \mathrm{NaCl}+$ 1 mM BTA (pH 6.3), in which the passive region was not defined clearly. In the other cases, the positive potential scan showed an apparent anodic current density in Region 1, which involved at least the passive layer formation and the $\mathrm{Cu}$ corrosion currents.

The relative magnitude of these contributions changed according to the composition of the aggressive solution. Otherwise, when $\mathrm{E}$ exceeded a certain critical value $\left(E_{b}\right)$, an abrupt increase in the anodic current was observed. Potentiostatic current transients run at $E>E_{b}$ showed localized corrosion of 


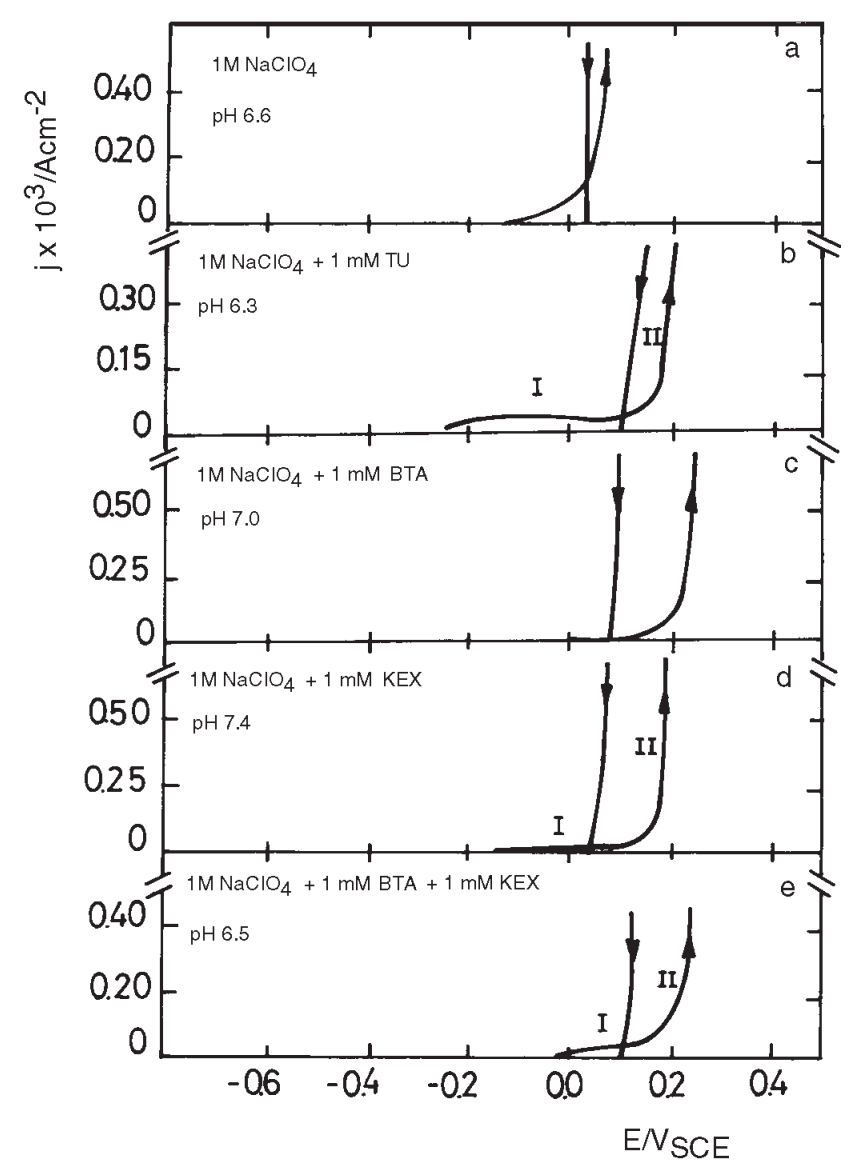

FIGURE 2. Polarization curves of electropolished, annealed $\mathrm{Cu}$ specimens run at $\mathrm{v}=0.001 \mathrm{~V} \mathrm{~s}^{-1}$ from $E_{s, c}=-0.80 \mathrm{~V}$ in $1 \mathrm{M} \mathrm{NaClO}_{4}$ containing different inhibitors $(6.2 \leq \mathrm{pH} \leq 7.4$ range) at $25^{\circ} \mathrm{C}$. Arrows indicate the potential scan direction. The reverse scan is drawn to $E_{r}$.
$\mathrm{Cu}$ occurred. Thus, the value of $\mathrm{E}_{\mathrm{b}}$ could be considered the breakdown potential of $\mathrm{Cu}$ in these aggressive solutions. $\mathrm{E}_{\mathrm{b}}$ values were obtained by extrapolating the branch of the anodic polarization curve related to localized corrosion of $\mathrm{Cu}$ to $\mathrm{j}=0$. The return potential scan showed a clear hysteresis loop and $\mathrm{Cu}$ repassivation at the potential $\mathrm{E}_{\mathrm{r}}<\mathrm{E}_{\mathrm{b}}$. In contrast, for $\mathrm{Cu}$ in $0.1 \mathrm{M} \mathrm{NaCl}, 1 \mathrm{M} \mathrm{NaClO}_{4}$, and $0.1 \mathrm{M} \mathrm{NaCl}+1 \mathrm{mM}$ $\mathrm{BTA}$, in the $6.2 \leq \mathrm{pH} \leq 7.6$ range, the increase of the anodic current was related mainly to a generalized $\mathrm{Cu}$ attack. The cathodic polarization curves at $E<E_{b}$ displayed several cathodic current contributions involving the reduction of different soluble $\mathrm{Cu}$ containing species.

The extent of these contributions depended strongly on the composition of the aggressive media, particularly on the nature of the inhibitor. The ability of each inhibitor to decrease the rate of $\mathrm{Cu}$ corrosion and to promote the onset of passivity could be determined by direct comparison of the polarization curves of $\mathrm{Cu}$ in the inhibitor-containing solutions and in the blank (Figures 1 and 2). Values of $E_{b}, E_{r}$, and $j_{a}$ and the anodic current density at $E=E_{b}-0.05 V$ measured in different solutions are summarized in Tables 1 and 2 . Values of $E_{b}$ and $E_{r}$, including $\sigma$ as the corresponding standard deviation, represented average values of at least 10 independent runs. In general, within $\pm \sigma$ the values of $E_{b}$ and $E_{r}$, the inhibiting effect of the different substances for Cu corrosion depended considerably on whether the electrolyte was $\mathrm{NaClO}_{4}$ or $\mathrm{NaCl}$, particularly for BTA and KEX. An interesting situation arose for the KEX-TU mixture. The error bar in the value of $E_{b}$ fluctuated between the $E_{b}$ values for these

TABLE 1

Breakdown and Repassivation Potentials and Apparent Passivating Current Density Values for Cu Specimens Anodized in $0.1 \mathrm{M} \mathrm{NaCl}$, at Different pH With Inhibitors (25ㄷ)

\begin{tabular}{|c|c|c|c|c|}
\hline Composition & $\mathrm{pH}$ & $\begin{array}{l}\mathrm{E}_{\mathrm{b}} \\
\mathrm{V}\end{array}$ & $\begin{array}{l}\mathrm{E}_{\mathrm{r}} \\
\mathrm{V}\end{array}$ & $\begin{array}{l}10^{6} \mathrm{j}_{\mathrm{a}}^{(\mathrm{A})} \\
\mathrm{A} \mathrm{c \textrm {cm } ^ { - 2 }}\end{array}$ \\
\hline $1 \mathrm{mM}$ TU & 9.5 & $0.00 \pm 0.02$ & $-0.05 \pm 0.01$ & 97 \\
\hline $1 \mathrm{mM}$ TU & 10.7 & $0.01 \pm 0.02$ & $-0.05 \pm 0.01$ & 76 \\
\hline $1 \mathrm{mM}$ BTA & 9.0 & $-0.02 \pm 0.02$ & $-0.05 \pm 0.01$ & 31 \\
\hline $1 \mathrm{mM}$ BTA & 10.9 & $0.02 \pm 0.02$ & $-0.05 \pm 0.01$ & 30 \\
\hline $1 \mathrm{mM} \mathrm{KEX}$ & 7.6 & $-0.02 \pm 0.02$ & $-0.05 \pm 0.01$ & 51 \\
\hline $2 \mathrm{mM}$ KEX & 7.6 & $0.08 \pm 0.02$ & $-0.06 \pm 0.01$ & 59 \\
\hline $3 \mathrm{mM}$ KEX & 7.6 & $0.32 \pm 0.07$ & $-0.06 \pm 0.01$ & 52 \\
\hline $3 \mathrm{mM} \mathrm{KEX}$ & 9.0 & $0.33 \pm 0.07$ & $-0.06 \pm 0.01$ & 41 \\
\hline $3 \mathrm{mM} \mathrm{KEX}$ & 10.8 & $0.38 \pm 0.07$ & $-0.06 \pm 0.01$ & 85 \\
\hline $3 \mathrm{mM} \mathrm{KEX}+1 \mathrm{mM}$ TU & 7.1 & $0.30 \pm 0.20$ & $0.02 \pm 0.04$ & 108 \\
\hline $3 \mathrm{mM} \mathrm{KEX}+1 \mathrm{mM}$ BTA & 7.0 & $0.48 \pm 0.07$ & $0.02 \pm 0.02$ & 95 \\
\hline $3 \mathrm{mM} \mathrm{KEX}+1 \mathrm{mM}$ BTA & 9.0 & $0.57 \pm 0.10$ & $0.05 \pm 0.03$ & 101 \\
\hline $3 \mathrm{mM}$ KEX + $1 \mathrm{mM}$ BTA & 11.0 & $0.61 \pm 0.10$ & $0.00 \pm 0.03$ & 95 \\
\hline
\end{tabular}

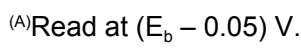


TABLE 2

Breakdown and Repassivation Potentials and Apparent Passivating Current Density Values for $\mathrm{Cu}$ Specimens Anodized in $1 \mathrm{M} \mathrm{NaClO}_{4}$ With and Without Inhibitor (25 $\mathrm{C}$ )

\begin{tabular}{|c|c|c|c|c|}
\hline Composition & $\mathrm{pH}$ & $\begin{array}{l}E_{b} \\
V\end{array}$ & $\begin{array}{l}\mathrm{E}_{\mathrm{r}} \\
\mathrm{V}\end{array}$ & $\begin{array}{l}10^{6} \mathrm{j}_{\mathrm{a}}^{(\mathrm{A})} \\
\mathrm{A} \mathrm{cm^{-2 }}\end{array}$ \\
\hline Plain $1 \mathrm{M} \mathrm{NaClO}_{4}$ & 9.2 & $0.08 \pm 0.05$ & $0.02 \pm 0.01$ & 133 \\
\hline Plain $1 \mathrm{M} \mathrm{NaClO}_{4}$ & 10.9 & $0.10 \pm 0.05$ & $0.01 \pm 0.01$ & 63 \\
\hline $1 \mathrm{mM}$ TU & 6.2 & $0.12 \pm 0.03$ & $0.08 \pm 0.01$ & 41 \\
\hline $1 \mathrm{mM}$ TU & 9.4 & $0.13 \pm 0.02$ & $0.09 \pm 0.02$ & 43 \\
\hline $1 \mathrm{mM}$ TU & 11.0 & $0.07 \pm 0.02$ & $0.07 \pm 0.02$ & 53 \\
\hline $1 \mathrm{mM}$ BTA & 7.0 & $0.18 \pm 0.02$ & $0.08 \pm 0.01$ & $<10$ \\
\hline $1 \mathrm{mM}$ BTA & 9.1 & $0.22 \pm 0.02$ & $0.05 \pm 0.01$ & $<10$ \\
\hline $1 \mathrm{mM}$ BTA & 11.0 & $0.23 \pm 0.02$ & $0.09 \pm 0.01$ & $<10$ \\
\hline $1 \mathrm{mM} \mathrm{KEX}$ & 7.4 & $0.07 \pm 0.05$ & $0.04 \pm 0.01$ & 72 \\
\hline $1 \mathrm{mM} \mathrm{KEX}$ & 9.4 & $0.08 \pm 0.04$ & $0.03 \pm 0.01$ & 51 \\
\hline $1 \mathrm{mM} \mathrm{KEX}$ & 10.9 & $0.11 \pm 0.04$ & $0.05 \pm 0.01$ & 75 \\
\hline $3 \mathrm{mM} \mathrm{KEX}$ & 7.6 & $0.06 \pm 0.04$ & $0.06 \pm 0.01$ & 31 \\
\hline $3 \mathrm{mM}$ KEX & 9.0 & $0.15 \pm 0.04$ & $0.06 \pm 0.01$ & 34 \\
\hline $3 \mathrm{mM} \mathrm{KEX}$ & 10.9 & $0.11 \pm 0.04$ & $0.06 \pm 0.01$ & 17 \\
\hline $1 \mathrm{mM} \mathrm{KEX}+1 \mathrm{mM}$ BTA & 6.5 & $0.21 \pm 0.02$ & $0.09 \pm 0.01$ & 45 \\
\hline $1 \mathrm{mM} \mathrm{KEX}+1 \mathrm{mM}$ BTA & 9.1 & $0.22 \pm 0.02$ & $0.09 \pm 0.01$ & 22 \\
\hline $1 \mathrm{mM} \mathrm{KEX}+1 \mathrm{mM}$ BTA & 10.9 & $0.22 \pm 0.02$ & $0.09 \pm 0.01$ & 20 \\
\hline $3 \mathrm{mM} \mathrm{KEX}+1 \mathrm{mM}$ BTA & 7.8 & $0.24 \pm 0.02$ & $0.08 \pm 0.01$ & 46 \\
\hline $3 \mathrm{mM} \mathrm{KEX}+1 \mathrm{mM}$ BTA & 9.0 & $0.22 \pm 0.02$ & $0.09 \pm 0.01$ & 51 \\
\hline 3 mM KEX + 1 mM BTA & 10.8 & $0.22 \pm 0.02$ & $0.09 \pm 0.01$ & 61 \\
\hline $3 \mathrm{mM} \mathrm{KEX}+1 \mathrm{mM}$ TU & 9.0 & $0.12 \pm 0.02$ & $0.08 \pm 0.01$ & 150 \\
\hline $3 \mathrm{mM} \mathrm{KEX}+1 \mathrm{mM}$ TU & 10.9 & $0.14 \pm 0.02$ & $0.07 \pm 0.01$ & 270 \\
\hline
\end{tabular}

(A)Read at $\left(E_{b}-0.05\right) \mathrm{V}$.

solutions containing either plain KEX or TU. The reason for these fluctuations was not clear but could be related to competitive adsorption of $\mathrm{KEX}, \mathrm{TU}, \mathrm{Cl}^{-}$, and $\mathrm{H}_{2} \mathrm{O}$ molecules at $\mathrm{Cu}$ sites.

\section{SEM Observations}

Micrographs of annealed $\mathrm{Cu}$ specimens without further electrochemical treatment (blanks) showed the presence of rounded $\mathrm{Cu}$ grains with a number of hemispherical micropits formed during electropolishing. ${ }^{6}$ For those $\mathrm{Cu}$ specimens anodized in solutions in which the passivity range was not defined clearly, a considerable generalized attack over the entire anodic polarization range and the accumulation of insoluble corrosion products was observed. Under these conditions, the formation of a $\mathrm{CuCl}$ film of nonuniform thickness was reported. ${ }^{8}$

Micrographs of $\mathrm{Cu}$ specimens in $0.1 \mathrm{M} \mathrm{NaCl}+1$ $\mathrm{mM}$ TU (pH 6.5) anodized at $-0.2 \mathrm{~V}$ (Figure 3[a]) revealed the formation of a netted film on Cu grains; whereas the results obtained after anodizing at $0.3 \mathrm{~V}$ (Figure 3[b]) exhibited a generalized attack that included pitting and a microcrystalline film assigned to corrosion products. Cu specimens in $0.1 \mathrm{M} \mathrm{NaCl}+$
$1 \mathrm{mM}$ BTA that were anodized at $-0.2 \mathrm{~V}$ showed the formation of a microcrystalline film assigned to a $\mathrm{BTA}-\mathrm{Cu}(\mathrm{I})$ complex, whereas those anodized at $0.3 \mathrm{~V}$ were coated with a thick layer of corrosion products. ${ }^{9}$ Otherwise, SEM micrographs of specimens in $0.1 \mathrm{M}$ $\mathrm{NaCl}+1 \mathrm{mM} \mathrm{KEX}$, anodized in region I (Figure 4[a]), showed the formation of a compact noncrystalline, thin layer covering the surface, including residual micropits from the electropolishing. The same system after anodizing in Region 2 at $0.3 \mathrm{~V}$ (Figure $4[\mathrm{~b}]$ ) showed the rupture of the protective layer and a clear localized attack of $\mathrm{Cu}$ leading to pitting. Similar features were shown for $\mathrm{Cu}$ specimens in $0.1 \mathrm{M} \mathrm{NaCl}+1 \mathrm{mM} \mathrm{KEX}+$ 1 mM BTA.

In general, SEM micrographs of $\mathrm{Cu}$ specimens after anodizing in Region 2 for $\mathrm{NaClO}_{4}+$ inhibitorcontaining solutions showed a certain density of pits distributed at random. The pit density, under comparable potential conditions, varied with the nature of the inhibitor and increased in the order KEX $<$ TU $<$ BTA, which was the inverse of the inhibitor ability sequence given for $1 \mathrm{M} \mathrm{NaClO}_{4}$ in the previous section. The SEM micrographs also revealed a certain amount of corrosion products formed around the pits. 


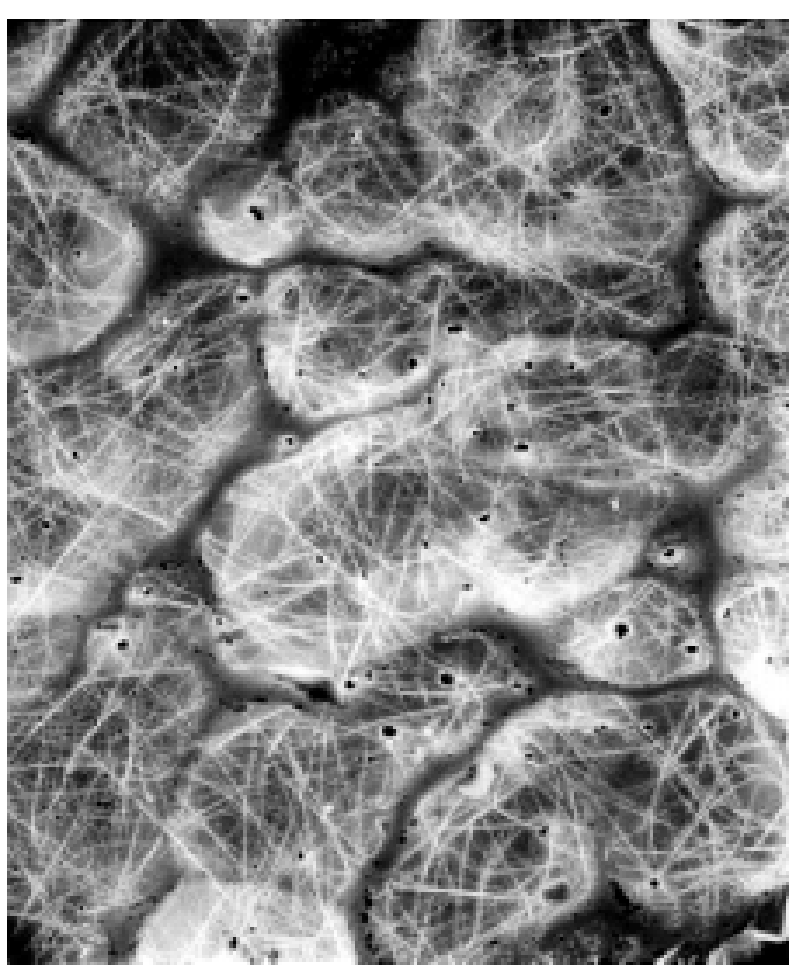

(a)

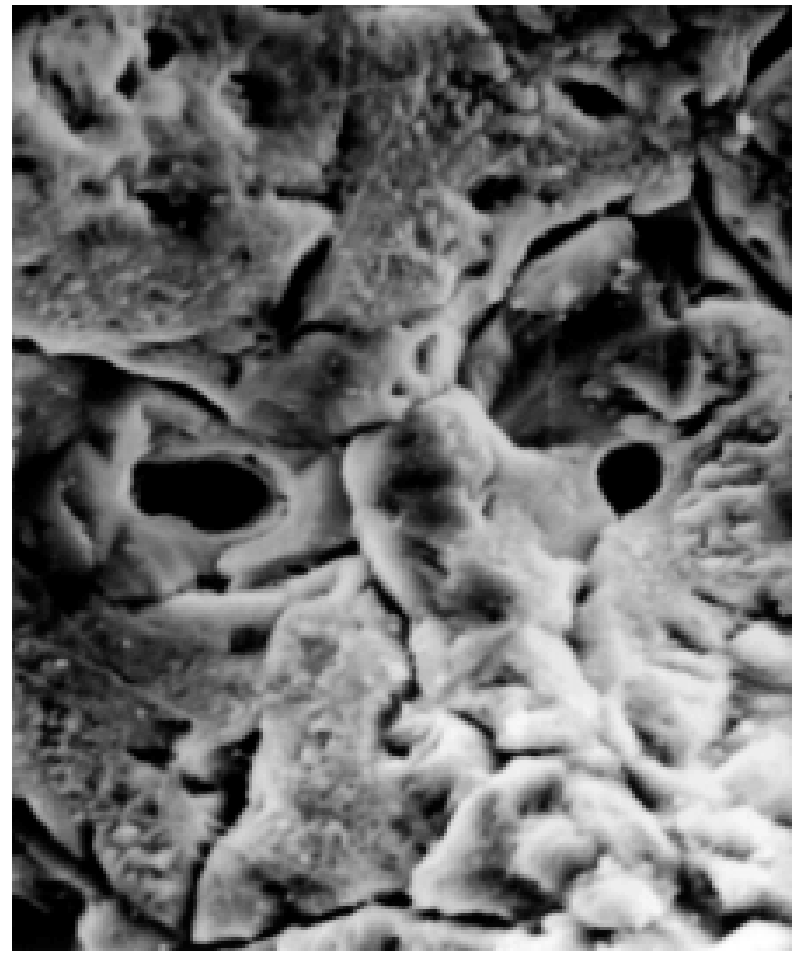

(b)

FIGURE 3. Micrographs of $\mathrm{Cu}$ specimens anodized in $0.1 \mathrm{M} \mathrm{NaCl}+x \mathrm{M}$ inhibitor $(6.3 \leq p H \leq 7.1$ range): (a) $0.1 \mathrm{M} \mathrm{NaCl}+1 \mathrm{mM} \mathrm{TU}$, specimen anodized at $-0.2 \mathrm{~V}$; and (b) $0.1 \mathrm{M} \mathrm{NaCl}+1 \mathrm{mM} \mathrm{BTA}$, specimen anodized at $0.3 \mathrm{~V}$.

The Cu specimens anodized at $0.3 \mathrm{~V}$ in $1 \mathrm{M}$ $\mathrm{NaClO}_{4}+1 \mathrm{mM}$ TU at $\mathrm{pH} 6$ were covered largely by a passivating layer with pits surrounded by corrosion products (Figure 5[a]). The passivating layer remained at $\mathrm{pH} 11$, although in this case, the layer appeared cracked and partially detached.

The corrosion of $\mathrm{Cu}$ in $1 \mathrm{M} \mathrm{NaClO}_{4}+1 \mathrm{mM} \mathrm{BTA}$ anodized in Region 2 developed crystallographic pits and generalized attack, with pits randomly distributed. ${ }^{10}$ The pit-free domains were covered by a microcrystalline layer as described. The latter coincided with the topography of thick Cu-BTA films formed on $\mathrm{Cu}^{9}{ }^{9}$ The pit density increased as the $\mathrm{pH}$ of the solution was raised from 7 to 11 .

Cu specimens in $0.1 \mathrm{M} \mathrm{NaClO}_{4}+3 \mathrm{mM} \mathrm{KEX}$ (pH 9) anodized in Region 2 showed formation of a nonhomogeneous, crystalline, island-structure porous film containing a number of small, pore-like domains (Figure 5[b]).

Finally, Cu specimens anodized in $0.1 \mathrm{M} \mathrm{NaClO}_{4}+$ $3 \mathrm{mM} \mathrm{KEX}+1 \mathrm{mM}$ BTA, anodized at potentials located in Region 2, showed the Cu surface still largely covered by a polymeric film similar to that for $1 \mathrm{M}$ $\mathrm{NaClO}_{4}+1 \mathrm{mM} \mathrm{KEX}$. The centers of attack probably were located at the boundaries among crystalline domains forming the passivating layer. For the solutions containing KEX-BTA at the same concentration ratio, the increase of $\mathrm{pH}$ from nearly 6 to approximately 11 produced no marked changes in the apparent structure of the protective layer and pit morphology.

\section{DISCUSSION}

The combination of electrochemical data and SEM observations established general trends in the behavior of the tested inhibitors for Cu protection in aqueous solutions containing aggressive species such as $\mathrm{Cl}^{-}$and $\mathrm{ClO}_{4}^{-}$ions in the $6.3 \leq \mathrm{pH} \leq 11$ range. Protection ability was displayed by shifting the $\mathrm{E}_{\mathrm{b}}$ values to more positive potentials. Protection ability could be related to surface characteristics such as surface coverage by passivating films and the ability to block local ruptures of the metal passive film.

The values of $E_{b}, E_{r}$, and $j_{a}$ in Tables 1 and 2 could be used as criteria for estimating the performance of the different substances as corrosion inhibitors for $\mathrm{Cu}$. The behavior of the various substances depended on whether $1 \mathrm{M} \mathrm{NaClO}_{4}$ or $0.1 \mathrm{M} \mathrm{NaCl}$ was used.

In $1 \mathrm{M} \mathrm{NaClO}_{4}, 1 \mathrm{M} \mathrm{NaClO}_{4}+\mathrm{BTA}$, and $1 \mathrm{M}$ $\mathrm{NaClO}_{4}+\mathrm{KEX}$, the values of $\mathrm{E}_{\mathrm{b}}$ increased slightly with solution $\mathrm{pH}$ in the $9.2 \leq \mathrm{pH} \leq 11$ range. But, the values 


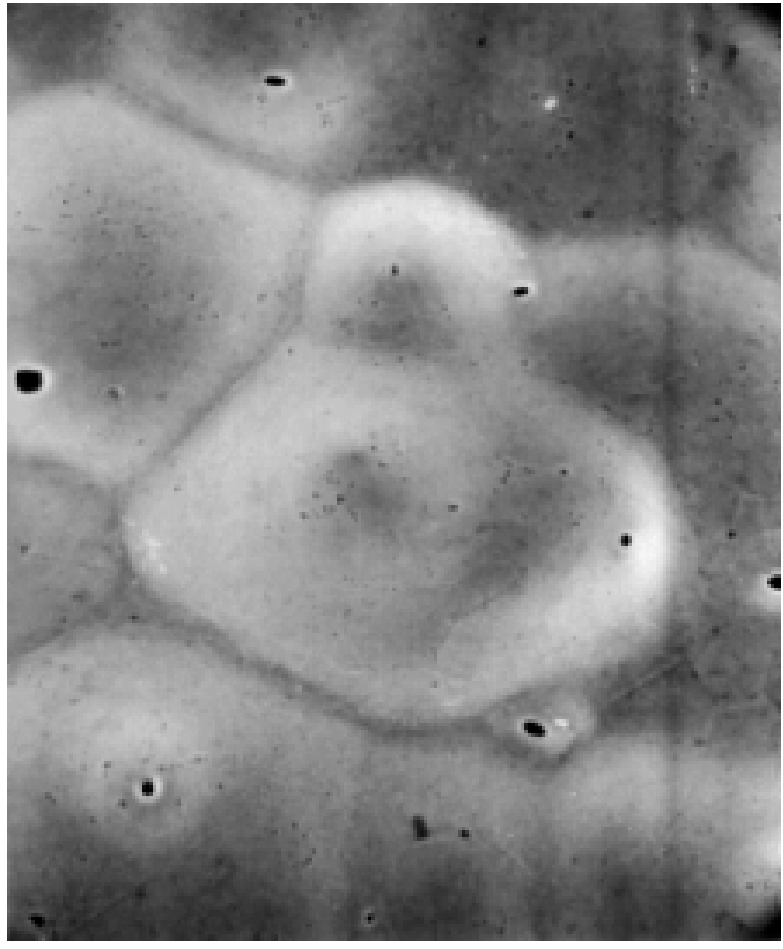

(a)

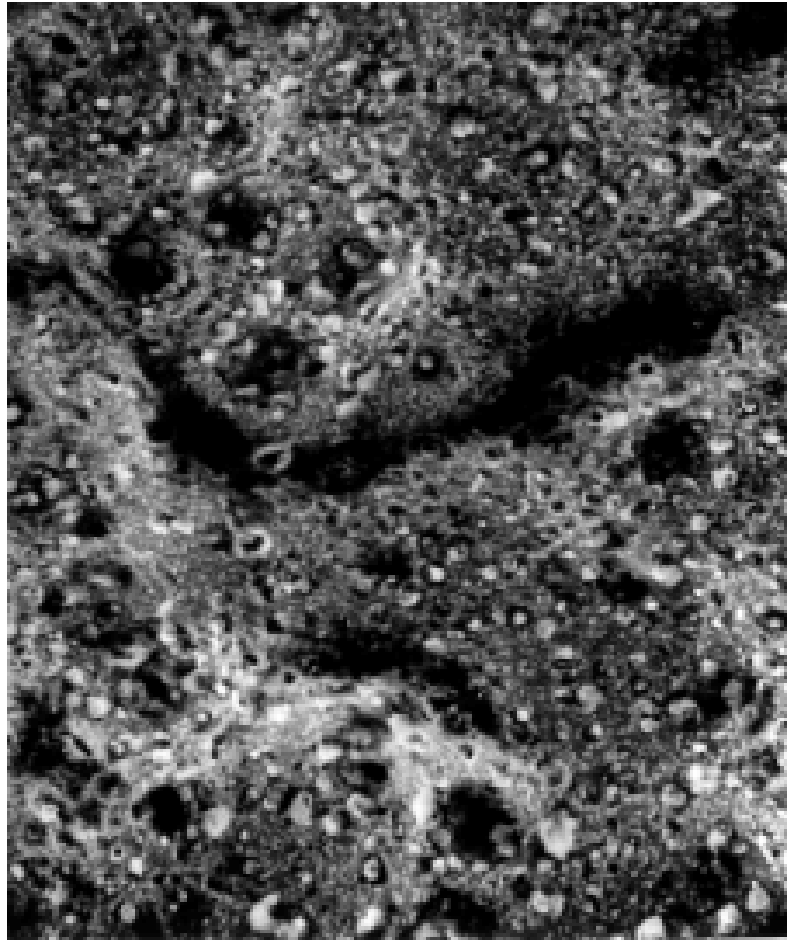

(b)

FIGURE 4. Micrographs of Cu specimens anodized in $0.1 \mathrm{M} \mathrm{NaCl}+1 \mathrm{mMKEX}$, at pH 7.6: (a) specimen anodized at $0.0 \mathrm{~V}$ (Region 1); and (b) specimen anodized at $0.3 \mathrm{~V}$ (Region 2).

decreased slightly for $1 \mathrm{M} \mathrm{NaClO}_{4}+\mathrm{TU}$ and remained almost constant for other systems. The values of $\mathrm{E}_{\mathrm{b}}$ were $0.10 \pm 0.05 \mathrm{~V}$ for those solutions containing TU, $\mathrm{KEX}$, and KEX + TU, and $0.22 \pm 0.02 \mathrm{~V}$ for those containing BTA. The values of $E_{r}$ indicated the passivating layer was rebuilt at potentials in the $0.05 \pm$ 0.01 to $0.09 \pm 0.01 \mathrm{~V}$ range. This common narrow potential window was consistent with a pit repassivation mechanism involving a change from acid salt to passive layer formation at the pit surface at $E<$ $\mathrm{E}_{\mathrm{r}}$.

Finally, the values of $\mathrm{j}_{\mathrm{a}}$ indicated BTA produced the most protective passivating layer at $\left(E_{b}-0.05\right) \mathrm{V}$. In this case, no synergistic effects were observed. BTA appeared to be the most effective substance to protect $\mathrm{Cu}$ in the aggressive solution.

The outer passive layer formed on $\mathrm{Cu}$ immersed in BTA-containing solutions at neutral and moderate alkaline $\mathrm{pH}$ levels in the absence of $\mathrm{Cl}^{-}$ions has been described as a polymeric, coherent, and continuous film, represented by the CuBTA basic stoichiometry. ${ }^{11-14}$ This layer is formed by the irreversible chemisorption of BTA in solution on the Cu surface in the $6 \leq \mathrm{pH} \leq 11$ range.

In $0.1 \mathrm{M} \mathrm{NaCl}$, the values of $\mathrm{E}_{\mathrm{b}}$ increased slightly with $\mathrm{pH}$ in the $7 \leq \mathrm{pH} \leq 11$ range, depending on the type of inhibitor. At a constant $\mathrm{pH}$ and inhibitor concentration, KEX was more efficient for $\mathrm{Cu}$ protection than TU and BTA. The addition of BTA to $K E X$-containing solution allowed the highest $E_{b}$ values. However, the values of $E_{r}$ were negative and almost the same within the error bars but increased in those solutions containing KEX-TU and KEX-BTA. The values of $j_{a}$ were in the $3 \times 10^{-5} \mathrm{~A} \mathrm{~cm}^{-2} \leq j_{a} \leq 1 \times 10^{-4} A$ $\mathrm{cm}^{-2}$, and no reliable dependence of $j_{a}$ on the nature of the inhibitor could be concluded.

In this case, KEX was a promising inhibitor in the presence of $\mathrm{Cl}^{-}$ions. For $0.1 \mathrm{M} \mathrm{NaCl}+1 \mathrm{mM} \mathrm{BTA}$, the structure of the Cu-BTA passive film did not fully protect the Cu substrate, probably because of the penetration of $\mathrm{Cl}^{-}$ions through the porous Cu-BTA film. Then, large pitted $\mathrm{Cu}$ surface areas were observed.

The adsorption of KEX rendered the metal surface hydrophobic, so the $\mathrm{H}_{2} \mathrm{O}-\mathrm{Cu}$ interactions were hindered. ${ }^{15} \mathrm{As} \mathrm{Cl}^{-}$ions were adsorbed on $\mathrm{Cu}$ from $-0.80 \mathrm{~V}$ upward, the formation of the KEX-Cupolymeric film was assisted by the presence of $\mathrm{Cl}^{-}$ions at the $\mathrm{Cu}$ surface. ${ }^{16}$ Hence, the stabilization of the inhibitor film structure should be assigned specifically to $\mathrm{Cl}^{-}$ion adsorption, as this effect was not observed in $1 \mathrm{M} \mathrm{NaClO}_{4}$. From both $\mathrm{E}_{\mathrm{b}}$ values and SEM micrographs, it appeared that $\mathrm{pH}$ played a minor role in determining the inhibitor ability of KEX on $\mathrm{Cu}$, within the $6 \leq \mathrm{pH} \leq 11$ range. 


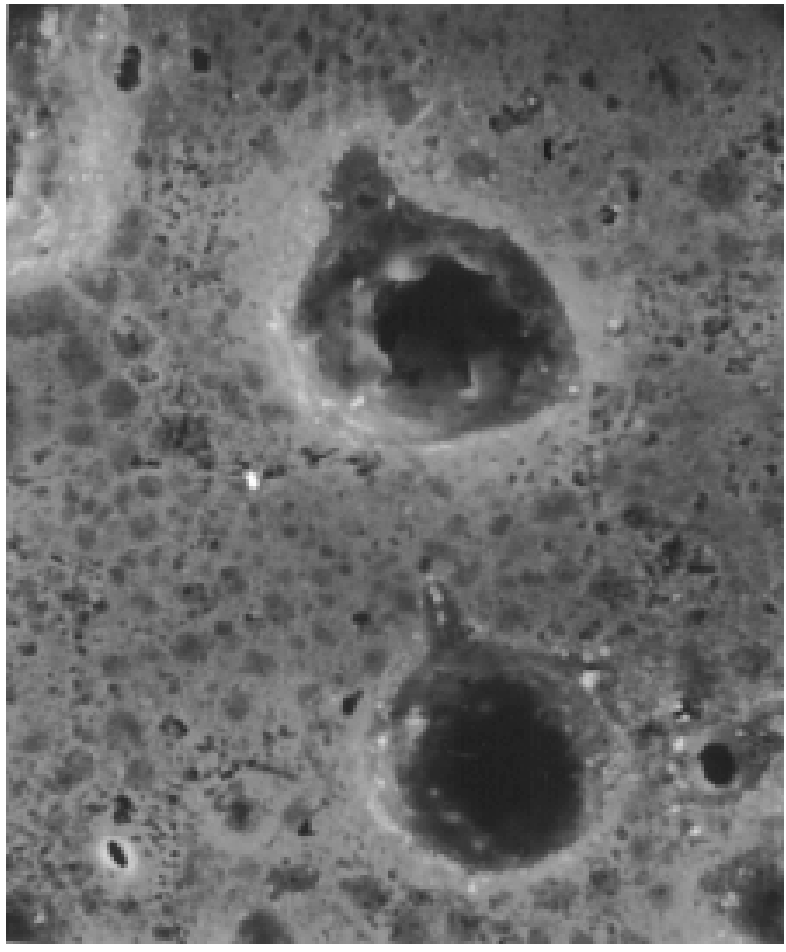

(a)

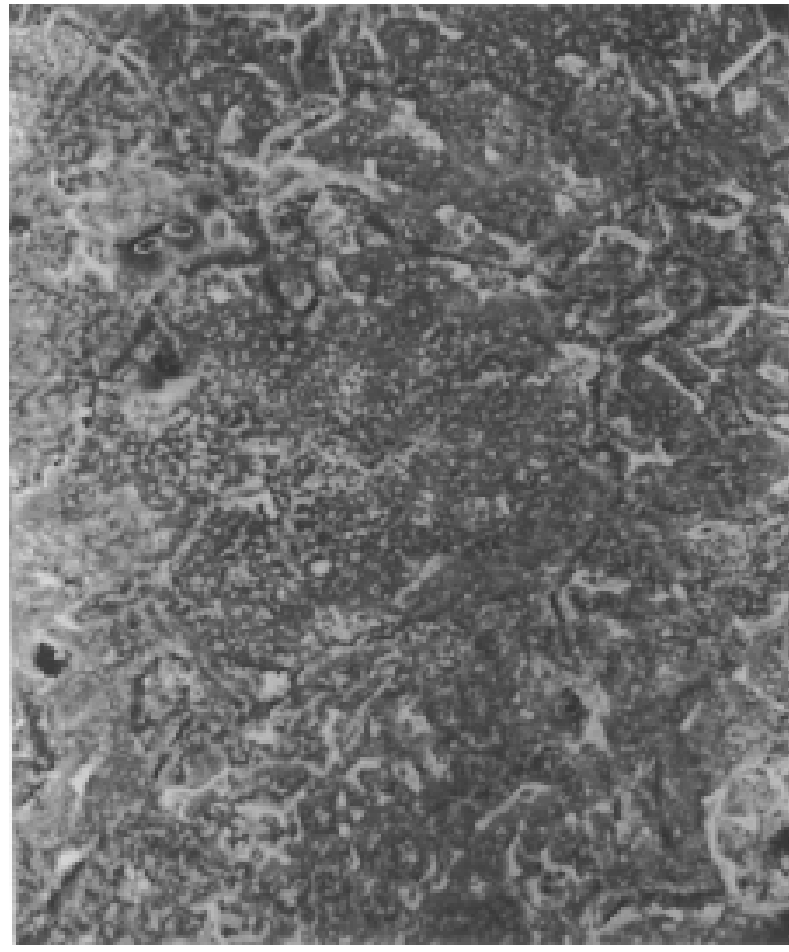

(b)

FIGURE 5. Micrographs of $\mathrm{Cu}$ specimens anodized in1 $\mathrm{M} \mathrm{NaClO}_{4}$ in the presence of different inhibitors at potential values within Region 2: (a) $1 \mathrm{M} \mathrm{NaClO}_{4}+1 \mathrm{mM} \mathrm{TU}$ at $\mathrm{pH} 6$ and (b) $1 \mathrm{M} \mathrm{NaClO}_{4}+1 \mathrm{mM} \mathrm{KEX}$ at pH 9.

\section{CONCLUSIONS}

Synergistic inhibiting effects were found for KEXBTA mixtures in medium containing $\mathrm{Cl}^{-}$ions. The synergistic effect was explained by an increase in the compactness of the passivating film.

$\square$ Previous kinetic studies of KEX have shown that the KEX passivating layer left small holes on the surface that became local corrosion sites at high positive potentials. ${ }^{4,17}$ The presence of BTA acted as a sort of sealing compound for those sites, probably participating directly in the formation of the KEX-Cupolymeric film structure involved in the passivating layer. The rupture of the latter leading to $\mathrm{Cu}$ pitting occurred at the highest values of $E_{b}$. Whether the sealing effect meant that two polymeric domains or a single copolymerized film was formed is a matter for further research. Nevertheless, the KEX-BTA mixture appeared to be a promising inhibitor for $\mathrm{Cu}$ corrosion in $\mathrm{Cl}^{-}$-containing solutions.

\section{ACKNOWLEDGMENT}

The financial support of the Gobierno de Canarias (Dirección General de Universidades e Investigación) under contract no. 46/01.06.88 and of Unión Eléctrica de Canarias is acknowledged.

\section{REFERENCES}

1. M. Fleischmann, I.R. Hill, G. Mengoli, M.M. Musiani, Electrochim. Acta 28 (1983): p. 1325.

2. M. Fleischmann, G. Mengoli, M.M. Musiani, C. Pagura, Electrochim. Acta 30 (1985): p. 1591.

3. W, Xingqing, Z, Yufu, Proceedings of the 10th International Congress on Metallic Corrosion, Madras (1987): p. 2799.

4. J. Gomez Becerra, R.C. Salvarezza, A.J. Arvia, J. of Appl. Electrochem. 17 (1987): p. 779.

5. O.P. Agrawal, I.K. Bhatnagar, V. Kumar, Proceedings of the 10th International Congress on Metallic Corrosion, Madras (1987): p. 2895.

6. M.M. Laz, R.M. Souto, S. Gonzalez, R.C. Salvarezza, A.J. Arvia, Electrochim. Acta 37 (1992): p. 655.

7. D. Dickertmann, F.D. Koppitz, J.W. Schultze, Electrochim. Acta 21 (1976): p. 967

8. M.R.G. de Chialvo, R.C. Salvarezza, D. Vasquez Moll, A. J. Arvia, Electrochim. Acta 30 (1985): p. 1501.

9. T. Notoya, G.W. Poling, Corrosion 32 (1976): p. 216

10. M.M. Laz, R.M. Souto, S. Gonzalez, R.C. Salvarezza, A.J. Arvia, J. Appl. Electrochem. 22 (1992): p. 1129.

11. J.B. Cotton, I.R. Scholes, Brit. Corros. J. 2 (1967): p. 1.

12. G.W. Poling, Corros. Sci. 10 (1970): p. 359.

13. R.F. Roberts, J. of Electronic Spectroscopy 4 (1974): p. 273.

14. T. Notoya, G.W. Poling, Corrosion 35 (1979): p. 193.

15. R. Woods, J. Phys. Chem. 75 (1971): p. 354.

16. C.I. Elsner, R.C. Salvarezza, A.J. Arvia, Electrochem. Acta 33 (1988): p. 1735.

17. R.O. Lezna, N.R. de Tacconi, A.J. Arvia, J. Electroanal. Chem. 255 (1988): p. 251 